\title{
Determination of Stunting Risk Factors Using Spatial Interpolation Geographically Weighted Regression Kriging in Malang
}

\author{
Henny Pramoedyo* ${ }^{* 1}$ Mudjiono ${ }^{1}$, Adji Achmad Rinaldo Fernandes ${ }^{1}$, Deby Ardianti ${ }^{1}$, \\ Kurniawati Septiani ${ }^{1}$ \\ 1. Department of Statistics, Faculty of Mathematics and Natural Sciences, Brawijaya University JI. Veteran, Malang, \\ Indonesia. 65145
}

DATA OF ARTICLE:

Received: 02 Jan 2020

Reviewed: 10 Mar 2020

Revised: 19 Jun 2020

Accepted: 30 Jun 2020

*CORRESPONDENCE:

pramoedyohp@yahoo.com

DOI:

10.18196/mm.200250

TYPE OF ARTICLE:

Research

\begin{abstract}
Stunting is a condition of toddlers who have less height than their age. The high percentage of stunting is influenced by several factors, namely access to healthy latrines, quality of drinking water, clean living habits, access to health services and exclusive breastfeeding. There is an indication that an area is reported as having high percentage of stunting, then the nearest area has the same condition. This study uses Geographically Weighted Regression Kriging spatial interpolation to predict risk factors for stunting by considering the proximity of the region. The data was secondary data obtained from each Puskesmas in Malang Regency, 2019. The observation unit is 24 sub-districts in Malang Regency. Based on the R2 value of the GWR model with a Fixed Gaussian Kernel weight, it is better to use than the weighted GWR Rook Contiguity model. It is known that in general the factors that influence stunting are Access to Posyandu, exclusive breastfeeding 1-6 Months, quality drinking water and Handwashing Behavior with soap. Prediction of Stunting Prevalence in Map Form Based on GWR Kriging Interpolation shows that stunting is high in several districts, namely Gedangan, Ampel Gading, Sumbermanjing Wetan, and Poncokusumo Districts
\end{abstract}

Keywords: stunting risk factor, GWR, Kriging

Abstrak: Stunting merupakan kondisi balita yang memiliki tinggi badan kurang dari usianya. Tingginya persentase stunting dipengaruhi oleh beberapa faktor yaitu akses jamban sehat, kualitas air minum, kebiasaan hidup bersih, akses pelayanan kesehatan dan pemberian ASI eksklusif. Ada indikasi bahwa jika suatu daerah mempunyai persentase stunting yang tinggi, maka daerah terdekatnya cenderung mempunyai kondisi yang sama. Penelitian ini menggunakan interpolasi spasial Geographically Weighted Regression Kriging untuk memprediksi faktor risiko stunting dengan mempertimbangkan kedekatan wilayah. Data penelitian merupakan data sekunder yang diperoleh dari masing-masing Puskesmas di Kabupaten Malang Tahun 2019. Unit observasi adalah 24 kecamatan di Kabupaten Malang. Berdasarkan nilai R2 model GWR dengan bobot Fixed Gaussian Kernel lebih baik digunakan daripada model Rook Contiguity dengan bobot GWR. Diketahui bahwa secara umum faktor yang mempengaruhi stunting adalah Akses ke Posyandu, Pemberian ASI Eksklusif 16 Bulan, Kualitas Air Minum dan Perilaku Cuci Tangan Pakai Sabun. Prediksi Prevalensi Stunting Dalam Bentuk Peta Berdasarkan GWR Kriging Interpolasi menunjukkan tingginya stunting di beberapa kabupaten, yaitu Kecamatan Gedangan, Ampel Gading, Sumbermanjing Wetan, dan Poncokusumo.

Kata Kunci: faktor risiko stunting, GWR, Kriging 


\section{INTRODUCTION}

Stunting is a condition where toddlers have less length or height if compared to age. ${ }^{1} \mathrm{~A}$ toddler stunting including chronic nutritional problems caused by various factors such as social-economy condition, maternal nutrition during pregnancy, pain in infants, and lack of nutrition in infants. ${ }^{2}$ The implication is that children who are stunted, sufferers of stunting can experience decreased neurodevelopmental and cognitive function and increase the risk of developing chronic disease. ${ }^{3}$

The stunting problem is a major nutritional problem faced by Indonesia. Based on Riskesdas data, stunting rates in Indonesia is $27,67 \%$ in 2019. Distribusi geografis prevalensi stunting di Indonesia menunjukkan bahwa belum ada wilayah di Indonesia yang terbebas dari stunting. Prevalensi tertinggi di beberapa wilayah di NNT dan Sulawesi tengah dan terkecil (<20\%) di DKI Jakarta. ${ }^{2}$

There is an assumption that if an area has a high stunting percentage, then the nearest area will experience the same condition. Thus, there should be statistical modelling method that involve information location in this research.

Spatial data is defined as data measurement which contain information location. Basic assessment of Spatial data is the law as stated by Tobler "Everything is related to everything else, but near things are more related than distant things".4,5 Geographically Weighted Regression (GWR) is a point approach technique linear regression model that will be the model weighted regression. Weight used in the GWR model can illustrate closeness of relations between regions. Accuracy weighting is needed because of weighting value represent the location of the data. ${ }^{6}$ Weights are grouped into two namely distance and area (contiguity). ${ }^{7}$

Model GWR is used to predict the observed value at each observation location, but observations outside the sample cannot be predicted by GWR Model. ${ }^{8}$ To overcomes these problems method Kriging can be used. Kriging is a technique geostatistics to predict and interpolating data at locations that not sampeled. ${ }^{9}$

Ordinary Kriging is used to estimate the value of observation on a specific location by observing the same data same in other location. Interpolation of ordinary kriging uses semivariogram, ${ }^{10}$ semivariogram divided by 2 namely namely experimental semivariogram and theoretical semivariogram. However, based on the model there are three types namely spherical, exponential dan gaussian. ${ }^{11}$ That method often used in several studies including research about stunting.
Based on both theory and research, the author interested in researching stunting cases in Malang Regency by using the spatial interpolation GWR Kriging with a weighthing matrix distance and area. The research variables are percentage of stunting, healthy latrines access, quality of drinking water, the habit of using soap hands, posyandu access coverage and exclusive breastfeeding 1-6 months. The result provides information about factors causes stunting and distribution maps of stunting in Malang Regency so that there should be a suitable policy from policy makers adjusted to each location.

The purpose of this research is to find out the factors causes stunting in 24 Districts of Malang Regency with the GWR method and create a prediction map of stunting distribution using kriging method with a distance and areas weighting matrix that can be used as a basis for policy regional determination stunting based on weighting of the analysis.

\section{MATERIALS AND METHOD}

Secondary data about stunting and risk fartors was obtained from each Puskesmas in Malang Regency year 2019. The observation unit was 24 sub-districts in Malang Regency. From the multiple linear regression analysis $R^{2}$ value was 0.22 , it has a small value. Geographically Weighted Resression method was used because there was heterogeneity in the data.

Spatial interpolation GWR kriging using a matrix weighting distance and area stages explained as follows:

1. Doing GWR analysis, including

a. Test spatial assumption namely heterogenity spasial using Breusch Pagan statistics test.

b. Determine the weighting distance,

i. Calculate euclide distance.

ii. Determine optimum bandwidth.

iii. Determine the weighting matrix Fixed Gaussian Kernel.

c. Determine the weighting area (Rook Contiguity).

d. Estimates parameter GWR models.

e. Testing the parameters of GWR models.

f. Determine of GWR Model with the best weighting.

2. Doing Kriging Analysis, including

a. Prepare a spatial data location map which is a map of the results of digitization contains data attribute information spatial 
b. To form the models of experiment and theorical semivariogram

c. To form the best semivariogram that is exponential model for interpolation stunting with the GWR models.

d. Make interpolation of contour maps stunting.

\section{RESULT}

The results of the GWR analysis on stunting data and several risk factors are presented sequentially according to the analysis process.

\section{Modelling GWR with Fixed Gaussian Kernel weighting}

Table 1 shows the value of optimum bandwidth with weighting Fixed Gaussian is 67905.23 . It means that the point inside radius 67905.23 considered influential optimal in forming parameters model. Other informations obtained is coefficients determination $\left(R^{2}\right)$ value in GWR model is 0.2650504 .

Table 1. Summary of Estimator Result GWR Model.

\begin{tabular}{cc}
\hline Bandwidth & 67905.23 \\
$\boldsymbol{R}^{2}$ & 0.2650504 \\
SSE & 740.2695 \\
\hline
\end{tabular}

Table 2. Subdistrict Grouping

\begin{tabular}{cll}
\hline Group & Subdistrict & \multicolumn{1}{c}{$\begin{array}{c}\text { Significant } \\
\text { Variables }\end{array}$} \\
\hline 1 & $\begin{array}{l}\text { Sumbermanjing } \\
\text { Wetan, Tirtoyudo, } \\
\text { Ampelgading, }\end{array}$ & $\begin{array}{l}\text { Access coverage } \\
\text { of Posyandu }\end{array}$ \\
& Poncokusumo & \\
\hline 2 & Donomulyo, & Access coverage \\
Kalipare, Pagak, & of Posyandu and \\
& Bantur, Gedangan, & exclusive \\
& Dampit, Wajak, & breastfeeding 1-6 \\
& Turen, Bululawang, \\
& months. \\
& Pagelanglegi, & \\
& Kepanjen, Sumber & \\
& Pucung, & \\
& Kromengan, & \\
& Ngajum, Wonosari, & \\
& Wagir, Pakisaji, & \\
& Tajinan, Tumpang & \\
\hline
\end{tabular}

\section{Modelling GWR with weighting Rook Contiguity}

Table 3 shows the result of GWR analysisi with weighting Rook Contiguity. There are 9 groups which is shown in Table 3.

Table 3. Subdistrict Grouping

\begin{tabular}{|c|c|c|}
\hline Group & Subdistrict & $\begin{array}{l}\text { Significant } \\
\text { Variables }\end{array}$ \\
\hline 1 & $\begin{array}{l}\text { Kalipare, Pagak, } \\
\text { Bantul, Gedangan, } \\
\text { Sumbermanjing } \\
\text { Wetan, Tirtoyudo, } \\
\text { Wajak, Pagelaran, } \\
\text { Kromengan, } \\
\text { Wonosari, Wagir, } \\
\text { Tajinan, dan } \\
\text { Tumpang. }\end{array}$ & - \\
\hline 2 & $\begin{array}{l}\text { Dampit, } \\
\text { Poncokusumo, } \\
\text { Pakisaji }\end{array}$ & $\begin{array}{l}\text { The access for } \\
\text { drinking water } \\
\text { quality }\end{array}$ \\
\hline 3 & Donomulyo & $\begin{array}{l}\text { Habit of using } \\
\text { soap hands }\end{array}$ \\
\hline 4 & $\begin{array}{l}\text { Gondanglegi, } \\
\text { Ngajum }\end{array}$ & $\begin{array}{l}\text { Exclusive } \\
\text { breastfeeding 1-6 } \\
\text { months }\end{array}$ \\
\hline 5 & Sumberpucung & $\begin{array}{l}\text { The access of } \\
\text { drinking water } \\
\text { quality and } \\
\text { exclusive } \\
\text { breastfeeding 1-6 } \\
\text { months }\end{array}$ \\
\hline 6 & Kepanjen & $\begin{array}{l}\text { Habit of using } \\
\text { soap hands and } \\
\text { Access coverage } \\
\text { of Posyandu. }\end{array}$ \\
\hline 7 & Turen & $\begin{array}{l}\text { The access of } \\
\text { drinking water } \\
\text { quality and } \\
\text { exclusive } \\
\text { breastfeeding } 1-6 \\
\text { months and } \\
\text { Access coverage } \\
\text { of Posyandu. }\end{array}$ \\
\hline 8 & Bululawang & $\begin{array}{l}\text { The access of } \\
\text { drinking water } \\
\text { quality and } \\
\text { exclusive } \\
\text { breastfeeding 1-6 } \\
\text { months, Access } \\
\text { coverage of } \\
\text { Posyandu, and } \\
\text { habit of using } \\
\text { soap hands }\end{array}$ \\
\hline 9 & Ampelgading & $\begin{array}{l}\text { Access coverage } \\
\text { of Posyandu and } \\
\text { exclusive } \\
\text { breastfeeding } 1-6 \\
\text { months }\end{array}$ \\
\hline
\end{tabular}


Table 2 shows two significant difference of variables which influence stunting. Access coverage of posyandu mostly causes stunting for Group 1. Different from group 1, not only access coverage of posyandu which causes stunting but also exclusive breastfeeding 1-6 months.

Group 1 in Table 3 shows absence variables that have a significant influence on stunting prevalence. In group 2 only variable access of drinking water quality that influence stunting prevalence. It was found in Dampit Poncokusumo and Pakisaji. Group 3 shows habit of using hand soap that influence stunting prevalence in Donomulyo. Group 4 shows that exclusive breastfeeding 1-6 months has a significant influence on stunting prevalence in the Gondanglegi and Ngajum. Seen in group 5 that the access of drinking water quality and exclusive breastfeeding 1-6 months give significant influence on stunting prevalence in Sumberpucung. Group 6 shows habit in using hand soaps, and coverage access of Posyandu has a significant influence on stunting prevalence in Kepanjen. In group 7 it is known that access of drinking water quality, coverage access of posyandu, and exclusive breastfeeding 1-6 Months has significant influence on stunting prevalence in Turen. Group 8 shows access of drinking water quality, habit in using hand soaps, coverage access of posyandu, exclusive breastfeeding 1-6 Months gives significant influence on stunting prevelence in Bululawang. Meanwhile, group 9 shows that coverage access of posyandu and exclusive breastfeeding 1-6 Months has an significant influence to the stunting prevalence in Ampelgading.

\section{Comparison GWR Method with weighting Fixed Gaussian Kernel and Rook Contiguity}

The comparison of GWR with the weighted method of Fixed Gaussian Kernel and Rook Contiguity is presented in Table 4. Based on Table 4, the $R^{2}$ values on GWR model with weighting Fixed Gaussian Kernel bigger compared to weighting Rook Contiguity. GWR model with weighting Fixed Gaussian Kernel is better to modelling stunting prevalence in Malang Regency and the interpolation GWR Kriging was caried out.

Table 4. Comparison $R^{2}$ values on GWR Model

\begin{tabular}{cc}
\hline Weighting & $R^{2}$ \\
\hline Fixed Gaussian Kernel & 0.26 \\
Rook Contiguity & 0.000064 \\
\hline
\end{tabular}

\section{Interpolation GWR Kriging}

The results of GWR kriging interpolation using exponential semivariogram are presented in the form of a prediction map to make it more informative and useful. Based on the prediction map in Figure 1, it is estimated that in 2019 the percentage of stunting is high in several areas in Malang Regency. In Figure 1, the high percentage of stunting is indicated by the red areas, namely Gedangan, Ampel Gading, Sumbermanjing Wetan, and Poncokusumo Subdistricts.

On the contrary, in the regional section the middle namely Gondanglegi Subdistrict has low percentage of stunting that marked on the map in dark green. The predicted value of stunting prevalence in this place by using Kriging GWR interpolation ranging from $14.7 \%$ to $16.9 \%$.

\section{DISCUSSION}

By using the weighting function Fixed Gaussian Kernel, CV Fixed Gaussian Kernel, CV minimum of 1834.053 and bandwidth minimum of 1834.053 and bandwidth amounted to 67905.23. GWR modeling is done by inserting a weighting with method weighted least square. Spatial weighting matrix for each location was used to form GWR model, so that each district has different models.
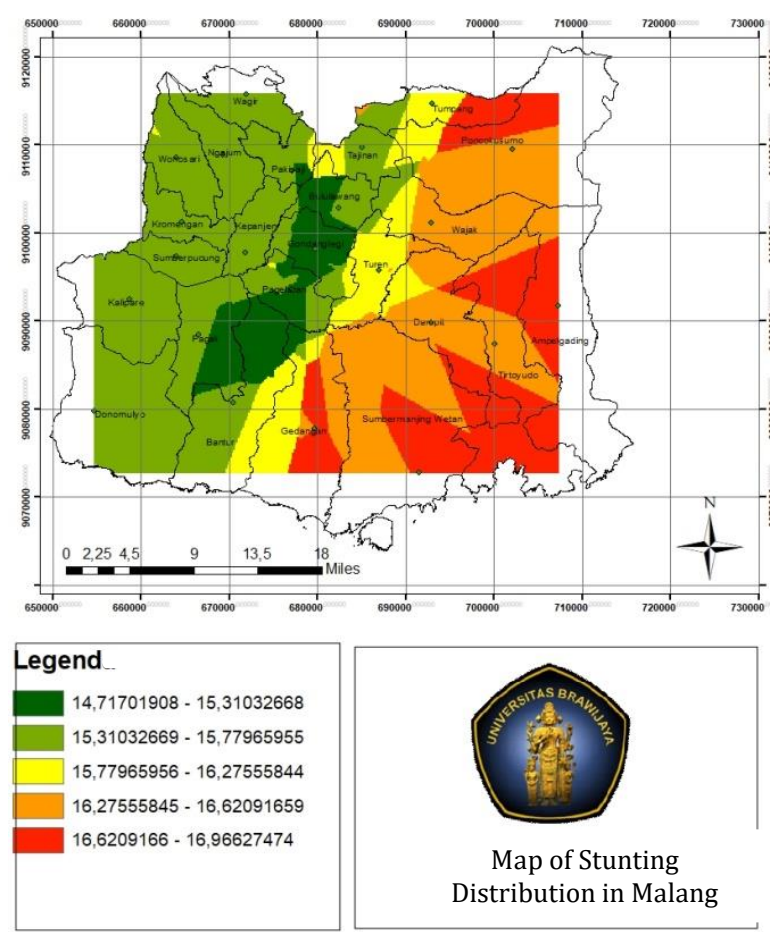

Figure 1 Prediction Map of Distribution Stunting di Malang Regency in 2019 
In the GWR model, there is significance testing parameter partially conducted to determine the parameters which has a significant effect with the following hypothesis: ${ }^{12}$

$H_{0}: \beta_{k}=0$

$H_{1}: \beta_{k} \neq 0 ; k=1,2,3$

Based on parameter significance testing in GWR model, it can be seen that significant variables are grouped in Table 2. In spatial data modeling using the area approach, one of them in this study was used Rook Contiguity, ${ }^{13}$ approach sides and angles, for GWR modelling. This weighting is used to determine GWR model parameters on each observation location.

After the parameters obtained at each subsequent observation location, then it used significance testing parameters partially to find out the parameter which has a significant influence to stunting prevalence, use weighting Rook Contiguity with hypothesis as follows. ${ }^{12}$

$H_{0}: \beta_{k}=0$

$H_{1}: \beta_{k} \neq 0 ; k=1,2,3$

Based on significance testing, there were grouping of significance variabels in Table 3. Table 3 shows that several factors that influence stunting in several areas in Malang Regency include exclusive breastfeeding 1 - 6 months, access to drinking water quality, coverage of posyandu and habit in using hand soap.

Stunting is a growth disorder of children who experience malnutrition, recurrent infections, ${ }^{14}$ inadequate psychosocial stimulation, ${ }^{15}$ and genetics. ${ }^{14}$ Undernutrition in children can result from uncovered exclusive breastfeeding for 1-6 months. Breast milk is the perfect food for babies, especially those aged 0-6 months because it contains nutrients needed for optimal baby's growth. ${ }^{16,17}$

Ease of access to drinking water is related to the availability of clean water facilities and infrastructure. According to Rohman and Syahrul (2017), ${ }^{18}$ the unavailability of clean water facilities and infrastructure will cause infectious diseases, especially infections of the digestive tract because they are related to the provision of healthy and clean food and drinks. In addition, the behavior of washing hands using soap is a part of a clean lifestyle that can prevent the entry of infectious agents, especially gastrointestinal infections. The availability of clean water facilities and infrastructure and the behavior of washing hands using soap are important in preventing the incidence of gastrointestinal infections. Digestive tract infections due to viruses, bacteria or parasites will reduce the body's ability to absorb nutrients from food intake so that the body will experience nutritional deficiencies. If this happens to children, it will hinder growth and development. In addition, digestive infections will also reduce appetite, cause vomiting and diarrhea in sufferers so that it will affect metabolism in the body which in turn will result in stunting in children. ${ }^{19}$

Comparison of analysis results based on weighting distance and area is done for find out the best weighting use $R^{2}$ value that presented on Table 4. Table 4 showed that GWR model with weighting Fixed Gaussian Kernel better to modelling prevalence stunting di Malang Regency. Geographically Weighted Regression Kriging interpolation using the exponential semivariogram method produces a prediction map (Figure 1). The forecast map in Figure 1 shows that in 2019 the estimated percentage of stunting is high in several districts, namely Gedangan, Ampel Gading, Sumbermanjing Wetan, and Poncokusumo Districts. In the middle section of the region, Gondanglegi District, the percentage of stunting is quite low. This informed the Malang Regency government to pay more attention to these districts regarding the prevention of stunting in children.

\section{CONCLUSION}

Variable which has a significant influence to the stunting prevalence on the GWR model is Coverage Access to Posyandu, exclusive breastfeeding 1-6 Months, quality of drinking water and habit in using hand soaps.

GWR model with distance weighting Fixed Gaussian Kernel better to use for modelling stunting data 2019 in Malang Regency. The predicted results of interpolation GWR Kriging with exponential semivariogram show that stunting is high in several districts, namely Gedangan, Ampel Gading, Sumbermanjing Wetan, and Poncokusumo Districts.

\section{Acknowledgement}

We would like firstly thank to BPPM Faculty of Mathematics and Natural Sciences, Brawijaya University that has funded this research and secondly thank to Publick Health Office Malang Regency to use his data and to anonymous reviewer to this paper

\section{REFERENCES}

1. Ministry of Health RI. Short Toddler Situation (Stunting) di Indonesia. Jakarta: Ministry of Health RI. 2019.

2. TNP2K. Buku Ringkasan Stunting. Jakarta: TNP2K 
RI. 2019.

3. de Onis M, and Branca F, "Childhood stunting: a global perspective,” Matern. Child. Nutr., 2016: 12(S1):12-26. doi: $10.1111 / \mathrm{mcn} .12231$.

4. Anselin L. Spatial Econometrics: Methods and Models, Vol. 4. Dordrecht: Springer Netherlands, 1988.

5. Fotheringham AS, Brunsdon C, and Charlton M. Geographically Weighted Regression: The Analysis of Spatially Varying Relationships. John Wiley \& Sons, 2003.

6. Yrigoyen CC, Rodríguez IG, and Otero JV. Modeling Spatial Variations in Household Disposable Income with Geographically Weighted Regression. Madrid: Instituto L.R. Klein, 2006). p. 40

7. Anselin L, Syabri I, dan Kho Y. "GeoDa: An Introduction to Spatial Data Analysis," dalam Handbook of Applied Spatial Analysis: Software Tools, Methods and Applications. Fischer MM and Getis A. Ed. Berlin, Heidelberg: Springer, 2010, pp. 73-89.

8. Jetz W, Rahbek C, and Lichstein JW. Local and global approaches to spatial data analysis in ecology. Glob. Ecol. Biogeogr. 2005: 14 (1): 97-98. doi: 10.1111/j.1466-822X.2004.00129.x.

9. Armstrong M. Basic Linear Geostatistics. Berlin Heidelberg: Springer-Verlag. 1998.

10. Isaaks EH, Isaaks ASEH, and Srivastava RM. Applied Geostatistics. Oxford University Press. 1989.

11. Setyadi B. Variogram Models. http://geodesy.gd.itb.ac.id/bsetyadji/wpcontent/ uploads/2007/09/gd4113-4b.pdf. Accessed 29 February 2020.

12. Lailiyah $\mathrm{N}$, and Purhadi. Modelling the factors that influince the level of illiteracy of regency in East Jawa Using GWLR. Sains Jurnal, 2012:1: 213-218.

13. Lesage JP. The Theory and Practice of Spatial Econometrics. Ohio; University of Toledo. 1999.

14. Priyono DIP, Sulistiyani, dan Ratnawati LY. Determinan Kejadian Stunting pada Anak Balita Usia 12-36 Bulan di Wilayah Kerja Puskesmas Randuagung Kabupaten Lumajang. EJournal Pustaka Kesehatan. Mei 2015: 3(2): 349-355

15. Nahar B. Effect of Food Supplementation and Psychosocial Stimulation on Growth and development of Severely Malnourished Children (Intervention Studies in Bangladesh). Dissertation. Faculty of Medicine, Uppsala University Bangladesh. 2012

16. Mawaddah S. Hubungan Pemberian ASI Eksklusif dengan Kejadian Stunting pada Balita Usia 24-36 Bulan. Jurnal Berkala Kesehatan, November 2019: 5(2), 60-66. DOI: 10.20527/jbk.v5i2.7340

17. Arum P, dan Widiyawati A. Kandungan Gizi ASI (Air Susu Ibu) pada Berbagai Suhu dan Lama Penyimpanan. Jurnal Ilmiah Inovasi; 2016:16(3): 200-203
18. Rohmah N, dan Syahrul F. Hubungan Kebiasaan Cuci Tangan dan Penggunaan Jamban Sehat dengan Kejdian Diare Balita. J. Berk. Epidemiol. 2017: 5:95-106

Tandang VS, Adianta IKA, Nuryanto IK. Hubungan ASI Eksklusif dan Riwayat Penyakit Infeksi dengan Kejadian Stunting pada Balita di Wilayah Puskesmas Wae Nakeng Tahun 2018. Jurnal Riset Kesehatan Nasional: 2019:3(1);128-133 